\title{
Study on Financial Management Model under Dynamic Information Age Jia Zhang ${ }^{1, \text { a }}$ \\ ${ }^{1}$ Nanchang Institute of Science \& Technology, Nanchang, Jiangxi, 33000 \\ a email
}

Keywords: Information Age, Dynamic Financial Management, Mode of Study, Countermeasures

\begin{abstract}
With the progress and development of market economy, modern science and technology to achieve a greater degree of development of means of information has a relatively wide range of applications in all aspects of social life and production. On enterprise management mode, the application of information technology means to promote a shift in corporate financial management model. Dynamic financial management model in this article will be under the age of information technology research and analysis, and the corresponding countermeasures.
\end{abstract}

\section{Introduction}

With modern science and technology to enhance the level of information technology in all aspects of social life and production have a greater degree of application. Under the information age, people's way of living and production will follow some changes, transmission information data will be more efficient, to enhance the efficiency of production and people's social life. For the company's financial management, the arrival of the information age, to the enterprise management model has brought opportunities and challenges. How the financial management improvements and adjustments to meet the development needs of the information age, so that enterprises can be sustainable development, to ensure that enterprises operating in the market economic activities, is under the background of the information age, businesses need pay attention to the problem.

\section{Traditional Enterprise Financial Management Mode Problems}

In the traditional corporate financial management, for the management and control of funds there is management is not clear, the cash flow is more chaotic situation, which for the financial management has a certain influence, is not conducive to the normal corporate financial operations use. In the traditional corporate financial management, the use of the relevant funds and issued are also not fully clear, the lack of management and control related specialized personnel, the company's financial cash flow is often difficult to relatively more smoothly carried out, which to some extent the enterprise had an impact on cash flow [1].

In the traditional corporate financial management, there is no budget to achieve sufficient attention. When companies lack a reasonable budget mechanism, the enterprise financial control of funds there will be some problems, it is difficult to effectively control and resolve the financial problems of enterprises so that enterprises use the financial resources were not effectively. In addition, the traditional corporate financial management mode there is also a lack of supervision and control of an organization issues, corporate finance is often difficult to use with a guarantee of transparency, which gives the company's financial accounting of funds brought a certain degree of difficulty, companies can not effectively informed of the financial financial situation, it is difficult to develop appropriate and reasonable financial plan based on the specific financial situation is not conducive to long-term business to achieve progress and development.

Although companies use computerized accounting can improve the efficiency of financial accounting, financial accounting can make faster and more convenient, improve work efficiency. However, the traditional corporate financial management, computerized accounting will not be applied to the financial management process, but simply the application of computerized accounting technology in the financial sector, computerized accounting no reasonable use of scientific, biased simple mechanical apply, it is difficult to help enterprise financial management information 
technology building.

In the traditional corporate financial management, group enterprise management and control, the need to ensure that the head office to keep abreast of business conditions and access to the branch, branch to get sufficient financial data to facilitate the formation of the head office branch specific understand the operating conditions, to facilitate the overall development direction and path Manpower Corporation group of companies to develop a reasonable development plan, assign the appropriate tasks [2]. However, traditional financial management model, the company was unable to timely access to relevant information, the group of enterprises can have poor overall management ability, is not conducive to group of business progress and development.

\section{Enterprise Financial Management Mode under Information Age}

Arrival of the information age, the impact of the production structure of society, changing people's life and production activities. Application of information technology, it is possible to enhance the rate of transmission of information to a large extent, social life and production activities are more efficient, data can get rid of geographical and time constraints, and to share and transfer high rate. In this context, enterprises in order to meet the development needs of the information age, should focus on the construction of information, corporate financial management to improve and perfect, establish and improve the financial management information system, and build information-based financial management platform efforts to improve financial management information for enterprises. Arrival of the information age, a profound impact on the progress and development of the production, supply, transportation, cost control, sales management and other aspects, means of information and computer technology, changing the traditional enterprise operation and management mode, through the application of information technology technology, the company's financial management can be a greater degree of progress and development, promote the upgrading of the level of financial management, enabling enterprises to achieve as soon as possible and improve the internal management optimization, have a stronger market competitiveness and ensure economic efficiency of enterprises [3]. The financial management improvements need to rely on existing information technology, make full use of financial software related to information technology, construction, and use of new financial management network platform, forming a complete set of the corresponding dynamic management of enterprise financial mechanisms to promote enterprise dynamic financial management. Finally, the emergence of the information era and the network of financial services derivatives, gave the financial management caused some impact. In the context of the information age, the company's financial management is only sufficient to absorb the existing information technology means, to ensure improve their financial management to adapt to the development needs of the information age, to ensure their own market conduct of operations, safeguard economic interests.

\section{Countermeasures under the Information Age of Dynamic Financial Management}

Dynamic financial management under the information age, the need to recognize the importance of the Group's financial information in the database, the database of financial information of the Group effective control, in order to play a role in the database. To this end, enterprises in the financial information and data related to your work, enhance their sense of responsibility to fully ensure the accuracy of financial information, and data can be related to the operation of the database specification and timely updated financial information database information, focusing on information tools application, using effective third party related to financial processing software to ensure the establishment and improvement of financial database to ensure that the update frequency database information, the database data will be sufficient monitoring and maintenance, database information to avoid data errors exist, so as to enterprises financial management provide sufficient reference information.

To ensure operational efficiency, so that their production and operation plans can have greater accuracy and operability, we should focus on the financial situation of enterprises understand and 
monitor, improve the transparency of financial situation of enterprises, so that enterprises can be based on the financial information in order to develop effective business plans of enterprises have to obtain a higher economic interest in the competition in the market, so as to promote their own progress and development. In addition, to ensure the security of corporate financial data, the need to finance the company's internal departments, strict grading system, so that the flow of relevant, state financial data processing and information and so can be the difference between protection, financial information can be perfect protection, to ensure normal production and operation activities.

In order to ensure a dynamic enterprise financial management, meet the development needs of the information age, companies should ensure that the Group's internal financial unified management and control, so that the head office of the branch to achieve understanding of the relevant financial information to ensure that financial information is acquired and timeliness effectiveness, to adopt a more centralized management of dynamic enterprise financial management, reasonable co-ordination related financial activities planned, to avoid financial problems related to a large extent, to ensure the effectiveness and integrity of the Group's financial information, implementing Corporation and branches of financial data and information seamlessly, sharing and transfer of data information [4]. News financial management model is different from the traditional model of financial management, can use information technology tools to enhance the management level to ensure the company's progress and development.

\section{Conclusion}

In the context of development of the information age, the company's financial management is facing opportunities and challenges. In order to ensure business progress and development, companies need to continuously upgrade their information technology standards, and achieve the financial management improvement and perfection, focus on cost management, cost management and capital management and other aspects of management and control, to build dynamic model of financial management to improve financial management of enterprises, promote the enterprise to achieve long-term progress and development.

\section{References}

[1] Chang Yu. on dynamic financial management model under information age background [J]. Modern Marketing (HEAD), 2015,10: 130.

[2] Chen Yuxia. Dynamic Financial Management Mode under the Background of Information [J]. Contemporary Economic, 2015, 32: 80-81.

[3] Han Xue. dynamic financial management model under the information age [J]. Accounting learning, 2015,18: 91.

[4] Wei Xiaoxi. Based on Amanda under the Information Age financial management [J] Contemporary Economic, 2016,03: 46-47. 